Original research article

\title{
Adherence to hand hygiene in a hospital setting - a questionnaire survey focused on compliance with the use of gloves
}

\author{
Petra Búřilová ${ }^{1,2}$ *, Michal Pospíšil 1, 2, Dana Dolanová ${ }^{1,2}$, Jana Kučerová ${ }^{2}$, Veronika Štrombachová ${ }^{2}$, \\ Jan Mužík ${ }^{1,2}$, Lada Cetlová ${ }^{3}$, Andrea Pokorná ${ }^{1,2}$ \\ ${ }^{1}$ Masaryk University, Faculty of Medicine, Department of Nursing and Midwifery, Brno, Czech Republic \\ ${ }^{2}$ The Institute of Health Information and Statistics of the Czech Republic, Prague, Czech Republic \\ ${ }^{3}$ College of Polytechnics, Department of Health Care Studies, Jihlava, Czech Republic
}

\section{Abstract}

Introduction: Hand hygiene is considered one of the most important and effective measures for infection prevention and control. It also plays a vital role in reducing healthcare-associated/acquired infections. The main goal is to assess hand hygiene compliance - with a special focus on using gloves when providing care in inpatient settings.

Methods: A cross-sectional survey on compliance with hand hygiene was conducted in health care facilities in the Czech Republic in 2018 before the COVID-19 pandemic. The participants were from 80 inpatient health care providers in the Czech Republic. Responses were scored on a 6-level scale, from "always" (100 points) to "never" (0 points). Data analysis was performed using IBM SPSS Statistics version 22.

Results: The questionnaire was filled in by 2,049 health care personnel from 80 inpatient health care facilities in the Czech Republic. Respondents were further divided according to the medical specialty. Respondents worked in the field of internal medicine (43\%), surgical fields (28\%), psychiatry (14\%), long-term care facilities (9\%), and other non-classified fields (6\%).

Conclusions: The presented study verified the good level of declared compliance with hygiene standards in inpatient healthcare providers in the Czech Republic. Significant differences were found between the observed hand hygiene measures established in the Czech Republic and international best practices based on a high scientific evidence level. An appropriate measure would be to establish national clinical best practices based on convincing scientific evidence at the national level.
\end{abstract}

Keywords: Compliance; Gloves; Hand hygiene; Healthcare-associated/acquired infections; Standard precautions

\section{Introduction}

The hands of healthcare professional personnel are considered one of the most important factors in the prevention of developing an infection associated with healthcare (McLaws, 2015). Hand hygiene is one of the most important and effective measures for infection prevention and control. It also plays a vital role in reducing healthcare-associated/acquired infections (HCAI). The use of gloves falls into the category of personal protection equipment, and they are used to reduce the spread of microorganisms in the hospital environment (Erasmus et al., 2010). The basic principle of their use is to provide a mechanical barrier that reduces the risk of microflora transmission from the patients to the staff (and the other way around). It also partially protects the skin on the hands from the possible side effects of disinfectants and other chemicals used in healthcare facilities. The choice of the type of gloves depends on the type of expected intervention (Mathai et al.,
2010). The gloves must be latex or nitrile; the permeability must correspond to the purpose of their use and the degree of risk related to biological agents. The thickness of the gloves must not significantly reduce the sensitivity of the hands (Pittet et al., 2008).

Knowledge and good practice of proper hand hygiene, as well as adherence to aseptic procedures, are key elements in the prevention of HCAI in professionals. There is always a certain amount of risk that a patient will become infected with a hospital infection during hospitalization. The determining factor for diagnosis of HCAI is the site of transmission, not the site of the detected infection. More than 1.4 million people worldwide suffer from HCAI. It is estimated that in developed countries, $5 \%$ to $10 \%$ of patients admitted to acute in-hospital care will suffer HCAI (Gopal Rao et al., 2002; World Health Organization, 2006). In high-risk settings, such as intensive care units, more than a third of patients may be affected with HCAI (World Alliance for Patient Safety, 2009). Despite this, compliance with hand hygiene guidelines by healthcare

\footnotetext{
* Corresponding author: Petra Búřilová, Masaryk University, Faculty of Medicine, Department of Nursing and Midwifery, Kamenice 3, 62500 Brno, Czech Republic; e-mail: burilova@med.muni.cz http://doi.org/10.32725/kont.2021.006 
providers is still challenging (Vernon et al., 2003). Ensuring a standardized procedure in the Czech Republic is set out in Methodological Measure No. 5/2012 published in the Bulletin of the Ministry of Health $(\mathrm{MoH})$ of the Czech Republic. It determines the principles of personal hygiene, hand care, and safe preparation before nursing and medical procedures. The $\mathrm{MoH}$ defines in detail the partial procedures for hand washing and disinfection. These procedures were created to protect both professional caregivers and patients from microorganism's transmission. The main goal is to assess hand hygiene compliance - with a special focus on using gloves when providing care in inpatient settings.

\section{Materials and methods}

A cross-sectional survey on compliance with hand hygiene was conducted via online questionnaire in health care facilities in the Czech Republic (Pokorná et al., 2020). The standardized questionnaire "Standard precautions" (hereinafter referred to as SP) was used for data collection (Efstathiou et al., 2011). It included ten structured questions, and the questionnaire was validated by double-blind translation from English into Czech. The authors of the study added several items of socio-demographic nature (age, gender, level of education, years of practice, clinical field of medicine, type of hospital operation, job title) to identify the target population. The standardized part of the questionnaire contained non-neutral response choice items on the Likert scale (from "always" to "never"). Respondents assessed the frequency of compliance with basic hygiene requirements by choosing an option in the positive or negative spectrum of response.

The self-reporting questionnaire form was distributed electronically by a verified Adverse Event Reporting System (hereinafter referred to as AERS) contact person; usually a participating facility's quality manager. The data was collected in 2018 before the COVID-19 pandemic. The participation of all respondents was completely anonymous and voluntary. The electronic form of the questionnaire's distribution was a limitation of the study because the authors could not influence its complete and impartial answer. As the study was targeted at the healthcare facilities employees involved in the AERS pilot project, the authors assumed a higher degree of compliance and reliability in responses. The analysis was performed using IBM SPSS Statistics version 22 (level of significance $1 \%$ and $5 \%)$. The analysis studied the significance in both categories (response rate percentage $-\mathrm{pK}$ ) and index (mean - pI). The differences in the representation of responses between the compared groups, including the possibility of "not available", were tested using a maximum-likelihood chi-square test (results reported as $\mathrm{pK}$ ). The differences in the index values between the compared groups were evaluated using the Kruskal-Wallis test (results reported as $\mathrm{pI}$ ). The records without any response were excluded from the evaluation using the Kruskal-Wallis test. The differences in responses between the compared groups were considered significant if $\mathrm{pK}$ and $\mathrm{pI}$ were $<0.05$ (Pokorná et al., 2020).

\section{Characteristics of the research sample}

The study includes healthcare professionals from 80 inpatient health care providers in the Czech Republic. The same providers were also involved in a project of the AERS. The questionnaire was filled in by 2,049 health care personnel from 80 inpatient health care facilities in the Czech Republic. The statistical processing was performed in the final 2,016 ques- tionnaires, the remaining number of forms was discarded due to incomplete nature. The questionnaire was filled in by 234 men (11.6\%) and 1,782 women (88.4\%). The average age of the respondents was 44 years, the median age was 44 years, $50 \%$ of respondents ( 25 th -75 th percentile) were $36-53$ years old. Respondents were further divided according to the medical specialty. Most respondents worked in the field of internal medicine (43\%), surgical fields (28\%), psychiatry (14\%), longterm care facilities (9\%), and other non-classified fields (6\%).

\section{Results}

Respondents were divided into three groups based on working groups: physicians, non-medical health personnel at patient's bedside (hereinafter referred to as NHP-B, i.e. general nurse, midwife, practical nurse/former medical assistant, auxiliary personnel, pediatric nurse, perioperative nurse), and other NHP (hereinafter referred to as NHP-O, i.e. medical laboratory, radiological assistant, physiotherapist, health management, biomedical engineer, paramedic, nutritional therapist, pharmaceutical assistant, technical-economic worker, occupational therapist, speech therapist, pedagogue, psychologist, scientific-researcher, manager and dental assistant). The work position of most respondents was non-medical healthcare professional working at patient's bedside $(73 \%)$, physician $(16 \%)$ and other non-healthcare staff (11\%).

Targeted questions on compliance with hand hygiene standards were answered by respondents in the item "I wear gloves when exposure of my hands to body fluids is anticipated". The negative spectrum of answers meant choices: "never, exceptionally, sometimes", and the positive spectrum of answers meant choices: "often, usually, always". The highest level of adherence to good practice and thus a positive spectrum of answers was found in $99 \%$ of respondents (87\% "always", $10 \%$ "usually", 2\% “often"). Significant differences between individual medical fields and professions have not been verified ( $p>0.05$ ). The negative spectrum of answers ("sometimes", "rarely" and "never" options) was most common in the item "I will wash my hands after removing used gloves", in which only $60.8 \%$ of respondents chose the "always" option. Significant differences between individual medical fields and professions have not been verified $(p>0.05)$. We identified relatively common negative answers in the item "I avoid 'foreign' objects on my hands such as wearing rings, watches, bracelets, etc.". Physicians more often reported negative answers (sometimes, rarely, never). More positive results were found in the surgical fields, and a statistically significant difference was verified between medical specializations and fields (Fig. 1).

In the non-medical staff working at the patient's bedside, a positive result prevailed in all medical fields, mostly because the medical staff avoids carrying foreign objects in their hands. In the item "I wash my hands after the removal of gloves" a statistically significant dependence was demonstrated in individual categories of medical fields $(p=0.001)$. Respondents from surgical wards indicated that they washed their hands less often after removing gloves than respondents from psychiatric wards (Fig. 2).

In the other non-medical health personnel (NHP-O), the answers were similar to those in the NHP-B group. Only in the item "I will wash my hands after the intervention in the patient". Respondents from surgical departments reported answers in the negative spectrum (rarely) and respondents from psychiatric wards (sometimes and never) in comparison with respondents from other disciplines $(p=0.008)$, Fig. 3 . 


$\begin{array}{lc}\text { C: surgery } & N=91 \\ \text { I: internal } & N=161 \\ \text { P: psychiatry } & N=25 \\ \text { O: other } & N=51\end{array}$

I wash my hands after the removal of gloves.

I avoid foreign objects on my hands such as: rings, watches, bracelets, etc.

I wear gloves when exposure of my hands to body fluids is anticipated.

I wash my hands after the provision of care.

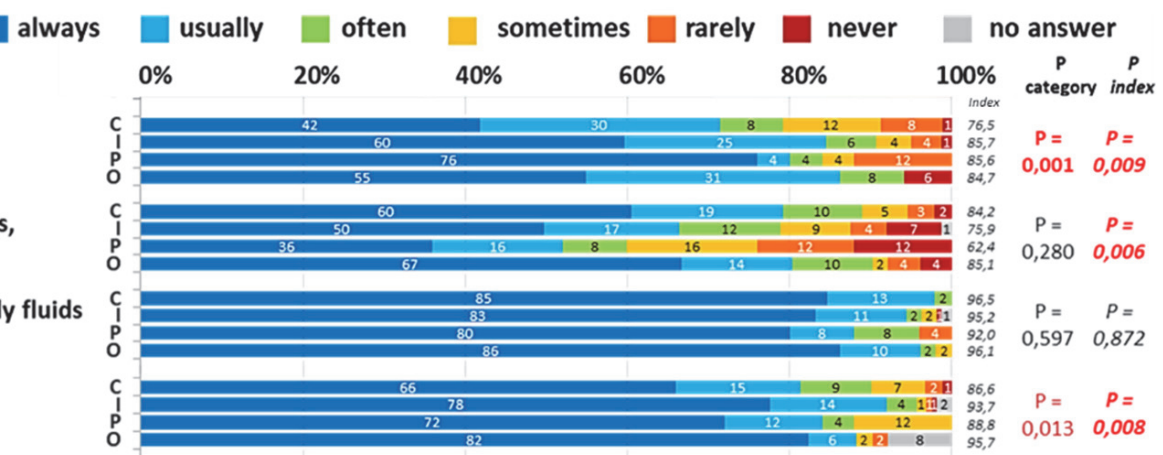

P category: M-L chi-square test Pindex: Kruskal-Walis test (ANOVA)

Fig. 1. Physicians' hand hygiene compliance according to the medical field

$\begin{array}{lr}\text { C: surgery } & N=468 \\ \text { I: internal } & N=658 \\ \text { P: psychiatry } & N=246 \\ \text { O: other } & N=97\end{array}$

I wash my hands after the removal of gloves.

I avoid foreign objects on my hands such as: rings, watches, bracelets, etc.

I wear gloves when exposure of my hands to body fluids is anticipated.

I wash my hands after the provision of care.

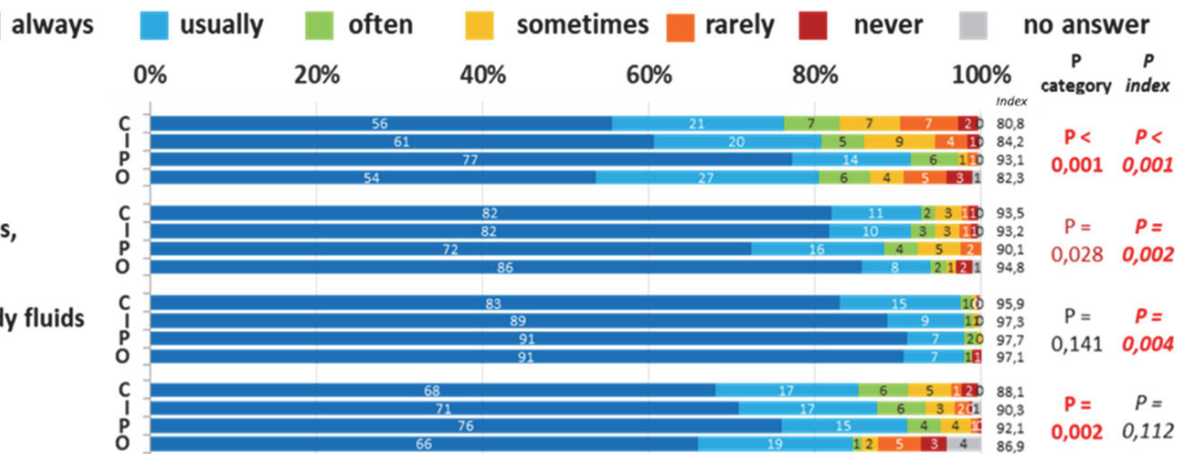

P category: M-L chi-square test P index: Kruskal-Walis test (ANOVA)

Fig. 2. Hand hygiene compliance of non-medical health personnel at the bedside according to the medical field

$\begin{array}{lr}\text { C: surgery } & N=16 \\ \text { I: internal } & N=49 \\ \text { P: psychiatry } & N=5 \\ \text { O: other } & N=149\end{array}$

I wash my hands after the removal of gloves.

I avoid foreign objects on my hands such as: rings, watches, bracelets, etc.

I wear gloves when exposure of my hands to body fluids is anticipated.

I wash my hands after the provision of care.

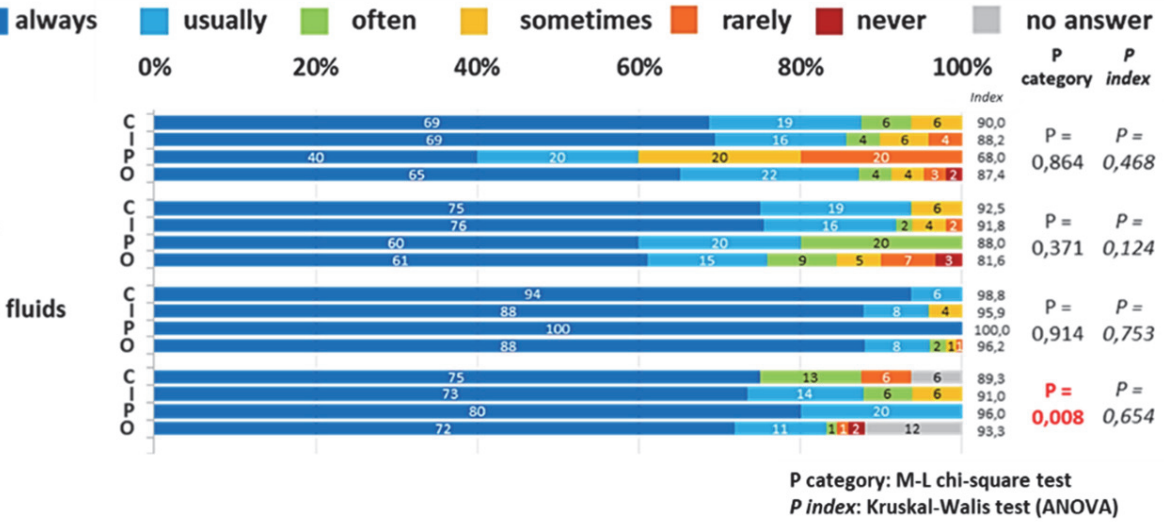

Fig. 3. Hand hygiene compliance of other NHP according to the medical field (NHP-B excluded)

\section{Discussion}

A questionnaire study among bedside personnel did not show significant differences in clinical practice in relation to compliance with hygiene standards with respect to the use of gloves.
For the item "I wash my hands after removing used gloves", a total of $60.8 \%$ of respondents chose the "always" option. There is a different methodological instruction in the Czech Republic in comparison to internationally accepted standards in this context. When using gloves, the respondents' answers follow the Czech legislation (or adhere to the internal regulations of indi- 
vidual medical facilities). Internal regulations determine that there is no need to wash hands after removing used gloves if they have not been damaged during the handling of infectious material or after any intervention in the patient (Methodological measure No. 5/2012 hand hygiene in the provision of health care; Decree No. 306/2012 Coll.). Internationally accepted best practices (based on evidence) implement an obligation to dispose of gloves after their removal and after every activity for which they were used, and perform hand hygiene afterward. These recommendations substantiate their claims with a healthy evidence level (Centers for Disease Control and Prevention, 2002; Kampf and Loffler, 2007; Kirkland et al., 2012). In the item "I avoid 'foreign' objects on my hands such as: wearing rings, watches, bracelets, etc.", up to $40 \%$ of responding physicians from the psychiatric wards and $20 \%$ of internal medicine physicians marked a negative spectrum of responses ("rarely, never"). This means almost half of the responding psychiatrists and every fifth internist do not respect the policy of wearing foreign objects on their hands while working in the healthcare settings. International Best Practices also set a high level of evidence for the claim that rings and bracelets should not be used by persons who are in direct contact with the client/patient. If the health care setting policy allows healthcare providers to wear jewellery on their hands, it must be limited to a single smooth wedding ring without stones (Jeans et al., 2010). Often, healthcare personnel identified as "other" personnel did not indicate any answer. It can be assumed that they do not encounter specific situations in their work. A foreign study showed the highest compliance with hygiene standards among health care workers working in emergency care units (Rosiński et al., 2019). The results of international studies also correspond to the results of our research. It is recommended to implement a multilateral and multidisciplinary hand hygiene program to minimize foreign objects on the hands, including cost-effective education, motivation, and systemic change (Marra and Edmond, 2012; Ontario Agency for Health Protection and Promotion, 2014). Continuous improvement of hand hygiene literacy among health care providers significantly reduces the rate of nosocomial infections and related morbidity and mortality (Dalziel et al., 2018). HCAIs are an increasingly essential and severe public health issue about which concerns have been expressed among all healthcare stakeholders, including doctors, nurses, allied health professionals, patients, and the public. Available evidence highlights that multimodal intervention strategies lead to improved hand hygiene and a reduction in HCAIs (Gould et al., 2010; Haque et al., 2020; Sadeghi-Moghaddam et al., 2015). It is therefore not appropriate to implement a single approach but multilevel education and a variety of methods.

\section{Conclusions}

The presented study verified good compliance with hygiene standards in inpatient healthcare providers in the Czech Republic. The study involved more than two thousand respondents. Significant differences between hand hygiene measures in the Czech Republic and international recommended procedures based on a high level of scientific evidence have been identified. As a result, a systemic change enabling the implementation of appropriate evidence-based procedures into practice is advised, especially regarding hygienic hand care and the use of gloves. The ideal measure would be to implement a national clinical best practice supported by strong scientific evidence.

\section{Ethics and consent}

The study was approved by the relevant committee. All the respondents were informed of their voluntary participation in the research study.

\section{Conflict of interests}

The authors have no conflict of interests to declare.

\title{
Dodržování hygieny rukou v nemocničním prostředí - dotazníkový průzkum zaměřený na zjištění compliance $\mathrm{v}$ použivání rukavic
}

\author{
Souhrn \\ Úvod: Hygiena rukou je považována za jedno z nejdůležitějších a nejúčinnějších opatření v prevenci a kontrole šírení infekcí. Hraje \\ také zásadní roli při snižování výskytu infekcí spojených se zdravotní péčí. Hlavním cílem je posoudit dodržování hygieny rukou - \\ se zvláštním zaměřením v používání rukavic při poskytování péče v lůžkových zařízeních. \\ Metody: Průřezový dotazníkový průzkum dodržování standardů bezpečné zdravotní péče v lůžkových zařízeních na území České \\ republiky v roce 2018 před pandemií COVID-19. Osloveno bylo celkem 80 lůžkových poskytovatelů zdravotních služeb v České \\ republice. Odpovědi byly hodnoceny na 6stupňové škále od „vždy“ (100 bodů) do „nikdy“ (0 bodů). Analýza dat byla provedena \\ pomocí IBM SPSS Statistics verze 22. \\ Výsledky: Dotazník vyplnilo 2049 zdravotnických pracovníků z 80 oslovených lůžkových zdravotnických zařízení na území České \\ republiky. Respondenti byli rozděleni dle medicínského oboru. Respondenti pracovali v interních oborech (43\%), chirurgických \\ oborech (28 \%), na psychiatrii (14 \%), v zařízeních dlouhodobé lůžkové péče (9 \%) a v ostatních nezařazených oborech (6 \%). \\ Závěr: Předkládaná studie ověřila dobrou úroveň v dodržování hygienických standardů u poskytovatelů lůžkové péče v České re- \\ publice. Identifikovány byly rozdíly v metodickém opatření pro hygienu rukou v České republice a mezinárodních doporučených \\ postupech, které jsou podloženy vysokou úrovní vědeckých důkazů. Vhodným opatřením by bylo zavést národně akceptované \\ klinické doporučené postupy s přesně vymezenou úrovní důkazů.
}

Klíčová slova: compliance; hygiena rukou; infekce spojené se zdravotní péčí; rukavice; standardy péče 


\section{References}

1. Centers for Disease Control and Prevention (2002). Guideline for Hand Hygiene in Health-Care Settings: Recommendations of the Healthcare Infection Control Practices Advisory Committee and the HICPAC/SHEA/APIC/IDSA Hand Hygiene Task Force. MMWR 51 (No. RR-16).

2. Dalziel C, McIntyre J, Chand AG, McWilliam S, Ritchie L (2018). Validation of a national hand hygiene proxy measure in NHS Scotland. J Hosp Infect 98(4): 375-377. DOI: 10.1016/j. jhin.2017.10.001.

3. Decree No. 306/2012 Coll. on the conditions for the prevention of the occurrence and spread of infectious diseases and hygienic requirements for the operation of medical facilities and social care institutions (2012). Collection of Laws of the Czech Republic. Prague: Ministry of the Interior of the Czech Republic. 109: 3957-3958.

4. Efstathiou G, Papastavrou E, Raftopoulos V, Merkouris A (2011). Compliance of Cypriot nurses with standard precautions to avoid exposure to pathogens. Nurs Health Sci 13(1): 53-59. DOI: 10.1111/j.1442-2018.2011.00576.x.

5. Erasmus V, Daha TJ, Brug H, Richardus JH, Behrendt MD, Vos MC, van Beeck EF (2010). Systematic review of studies on compliance with hand hygiene guideline in-hospital care. Inf Control Hosp Epidemiol 31(3): 283-294. DOI: 10.1086/650451.

6. Gopal Rao G, Jeanes A, Osman M, Aylott C, Green J (2002). Marketing hand hygiene in hospitals - a case study. J Hosp Infect 50(1): 42-47. DOI: 10.1053/jhin.2001.1119.

7. Gould DJ, Moralejo D, Drey N, Chudleigh JH (2010). Interventions to improve hand hygiene compliance in patient care. Cochrane Database Syst Rev (9): CD005186. DOI: 10.1002/14651858.CD005186.pub3.

8. Haque M, McKimm J, Sartelli M, Dhingra S, Labricciosa FM, Islam S, et al. (2020). Strategies to Prevent HealthcareAssociated Infections: A Narrative Overview. Risk Manag Healthc Policy 13: 1765-1780. DOI: 10.2147/RMHP.S269315.

9. Jeans AR, Moore J, Nicol C, Bates C, Read RC (2010). Wristwatch use and hospital-acquired infection. J Hosp Infect 74(1): 16-21. DOI: 10.1016/j.jhin.2009.06.032.

10. Kampf G, Loffler H (2007). Prevention of irritant contact dermatitis among health care personnel by using evidencebased hand hygiene practices: a review. Ind Health 45(5): 645-652. DOI: 10.2486/indhealth.45.645.

11. Kirkland KB, Homa KA, Lasky RA, Ptak JA, Taylor EA, Splaine ME (2012). Impact of a hospital-wide hand hygiene initiative on healthcare-associated infections: results of an interrupted time series. BMJ Qual Saf 21(12): 1019-1026. DOI: 10.1136/bmjqs-2012-000800.
12. Marra AR, Edmond MB (2012). Hand Hygiene: State-of-the-Art Review With Emphasis on New Technologies and Mechanisms of Surveillance. Curr Infect Dis Rep 14(6): 585-591. DOI: 10.1007/s11908-012-0288-y.

13. Mathai E, Allegranzi B, Kilpatrick C, Pittet D (2010). Prevention and control of healthcare-associated infections through improved hand hygiene. Indian J Med Microbiol 28(2): 100-106. DOI: 10.4103/0255-0857.62483.

14. McLaws ML (2015). The relationship between hand hygiene and health care-associated infection: it's complicated. Infect Drug Resist 8: 7-18. DOI: 10.2147/IDR.S62704.

15. Methodological measure No. $5 / 2012$ hand hygiene in the provision of health care (2012). Bulletin of the Ministry of Health of the Czech Republic. Prague: Ministry of Health of the Czech Republic. 5: 17-20.

16. Ontario Agency for Health Protection and Promotion (2014). Public Health Ontario, Provincial Infectious Diseases Advisory Committee. Best Practices for Hand Hygiene in All Health Care Settings. 4th ed. Toronto, ON Queen's Printer for Ontario.

17. Pittet D, Allegranzi B, Storr J, Bagheri Nejad S, Dziekan G, Leotsakos A, Donaldson L (2008). Infection control as a major World Health Organization priority for developing countries. J Hosp Infect 68(4): 285-292. DOI: 10.1016/j.jhin.2007.12.013.

18. Pokorná A, Dolanová D, Pospíšil M, Búřilová P, Mužík J (2020) Compliance with standard precautions in inpatient healthcare settings in the Czech Republic: a cross-sectional survey. Cent Eur J Public Health 28(3): 167-177. DOI: 10.21101/cejph. a5942.

19. Rosiński J, Różańska A, Jarynowski A, Wójkowska-Mach J, Polish Society of Hospital Infections Team (2019). Factors Shaping Attitudes of Medical Staff towards Acceptance of the Standard Precautions. Int J Environ Res Public Health 16(6): 1050. DOI: 10.3390/ijerph16061050.

20. Sadeghi-Moghaddam P, Arjmandnia M, Shokrollahi M, Aghaali M (2015). Does training improve compliance with hand hygiene and decrease infections in the neonatal intensive care unit? A prospective study. J Neonatal Perinatal Med 8(3): 221-225. DOI: 10.3233/NPM-15915001.

21. Vernon MO, Trick WE, Welbel SF, Peterson BJ, Weinstein RA (2003). Adherence with hand hygiene: does a number of sinks matter? Infect Control Hosp Epidemiol 24(3): 224-225. DOI: $10.1086 / 502193$.

22. World Alliance for Patient Safety (2009). WHO Guidelines on Hand Hygiene in Health Care. Geneva, Switzerland: World Health Organization.

23. World Health Organization (2006). World Alliance for Patient Safety. Manual for Observers. WHO Multimodal Hand Hygiene Improvement Strategy. 